\title{
An ecological study on suicide and homicide in Brazil
}

\author{
Estudo ecológico sobre suicídio e homicídio no Brasil
}

Daniel Hideki Bando ${ }^{1}$

David Lester $^{2}$
${ }^{1}$ Secretaria Municipal da Saúde de Guarulhos. Rua Iris 300 , Vila Iris. 07.051-080 Guarulhos SP Brasil.

danhideki@gmail.com ${ }^{2}$ The Richard Stockton College of New Jersey.
Abstract The objective was to evaluate correlations between suicide, homicide and socio-demographic variables by an ecological study. Mortality and socio-demographic data were collected from official records of the Ministry of Health and IBGE (2010), aggregated by state (27). The data were analyzed using correlation techniques, factor analysis, principal component analysis with a varimax rotation and multiple linear regression. Suicide age-adjusted rates for the total population, men and women were 5.0, 8.0, and 2.2 per 100,000 inhabitants respectively. The suicide rates ranged from 2.7 in Pará to 9.1 in Rio Grande do Sul. Homicide for the total population, men and women were 27.2, 50.8, and 4.5 per 100,000, respectively. The homicide rates ranged from 13.0 in Santa Catarina to 68.9 in Alagoas. Suicide and homicide were negatively associated, the significance persisted among men. Unemployment was negatively correlated with suicide and positively with homicide. Different socio-demographic variables were found to correlate with suicide and homicide in the regressions. Suicide showed a pattern suggesting that, in Brazil, it is related to high socioeconomic status. Homicide seemed to follow the pattern found in other countries, associated with lower social and economic status.

Key words Suicide, Homicide, Sociodemographic variables, Ecological study, States of Brazil
Resumo O objetivo foi avaliar a correlação entre homicídio, suicídio e variáveis sociodemográficas num estudo ecológico. Os dados foram coletados a partir de registros oficiais disponibilizados pelo Ministério da Saúde e IBGE (2010), agregados por estado. Os dados foram analisados usando técnicas de correlação, análise fatorial, análise de componentes principais com rotação varimax e regressão linear múltipla. As taxas de suicídio padronizadas por idade para o total, homens e mulheres foram 5,0; 8,0 e 2,2 por 100.000, respectivamente. A taxa de suicídio variou de 2,7 no Pará a 9,1 no Rio Grande do Sul. As taxas de homicídio para o total, homens e mulheres foram 27,2; 50,8 e 4,5 por 100.000, respectivamente. A taxa de homicídio variou de 13,0 em Santa Catarina a 68,9 em Alagoas. Suicídio e homicídio foram negativamente associados, a significância persistiu entre os homens. O desemprego foi negativamente correlacionado com o suicídio e positivamente com o homicídio. Diferentes variáveis sociodemográficas foram correlacionadas com o suicídio e homicídio nas regressões. Suicídio apresentou um padrão, sugerindo que no Brasil está relacionado com alto nível socioeconômico. Homicídio parece seguir o padrão encontrado em outros países, associado com baixo nível socioeconômico.

Palavras-chave Suicídio, Homicídio, Variáveis socioeconômicas, Estudo ecológico, Estados do Brasil 


\section{Introduction}

Suicide and homicide are a worldwide public health problem with about one million deaths from suicide occurring worldwide each year. There are wide variations in the suicide rates of the nations of the world, ranging from about 30 per 100,000 per year in Russia to less than 1 per 100,000 in Arab nations such as Egypt. The suicide rate also varies over regions within a country. For example, in the United States, suicide rates are higher in the western states and in those with higher rates of divorce and migration ${ }^{1}$. There are several published studies that have focused on the ecological association of suicide and homicide rates with sociodemographic aspects in different countries using a variety of indexes to explore these associations. However, almost all of the studies have been carried out in developed countries.

Brazil covers 8.5 million $\mathrm{km}^{2}$ ( $47 \%$ of South America), with an estimated population of 190 million inhabitants in 2010, the world's fifth most populous country ${ }^{2}$. The country is divided into 27 States with differing socioeconomic and health conditions. For example, according to the last national census, the wealthiest states, Distrito Federal (centre-west) and São Paulo (southeast) had a per capita income of US\$ 1392 and US\$ 857 , respectively. They contrasted strongly with the poorest state, Maranhão (north), with a per capita income of US\$392. The unemployment rate also showed great variability, ranging from the state with the lowest rate Santa Catarina (south), with $3.8 \%$, to the state with the highest rate, Amapa (north), with $11.9 \%{ }^{3}$.

Suicide rates in Brazil from 1980 to 2006 have increased from 4.4 to 5.7 per 100,000 inhabitants per year. Suicide among young Brazilians has increased in the state capitals of the country $y^{4,5}$. The average suicide rate was 4.9 which is low compared with the worldwide suicide rate $(14.5)^{6-8}$. Suicide rates in Brazilian regions also vary broadly, ranging from 2.7 (northeast) to 9.3 (south) ${ }^{7}$. Recent study confirmed this pattern, a spatial cluster of high suicide rates was identified in the southern part of Brazil ${ }^{9}$. Despite the importance of suicide as a public health problem and the availability of data in the official mortality records, the literature shows important epidemiological gaps in the understanding of the problem ${ }^{10}$.

Many risk factors that contribute to suicide are well known and include: genetic loading, personality characteristics (e.g., impulsivity and aggression), psychiatric and physical disorders (e.g., depression, pain and incapacity), life events (e.g., loss and trauma), social isolation, economic conditions, the availability of means for committing suicide, and substance abuse ${ }^{6,11}$. Ecological studies of suicide commonly study the impact of such variables as marital status, population density, birth rate, urban population, per capita income, unemployment rate, education and religious affiliation $^{6,12-17}$. The results have varied widely.

Durkheim's ${ }^{12}$ masterpiece, Le Suicide, inaugurated the modern age of sociology in the late $1^{\text {th }}$ Century and was one of the first ecological studies of suicide and a major influence in epidemiology and sociology. Durkheim noted that suicide rate was higher in northern France and that low family density and wealth were associated with higher suicide rates. Durkheim's theory of suicide was based on two concepts: social integration and social regulation. Suicidal behavior is common in societies where there is a low degree of social integration (leading to egoistic suicide). The individual is protected from egoism by religions with strong group ties (e.g. Roman Catholicism) and by family ties (e.g. marriage). Suicidal behavior is also common in societies where there is a low degree of social regulation (leading to anomic suicide). Social regulation can be understood as external regulatory forces on the individual (such as those produced by economic cycles) $)^{12,13}$. The other extremes of egoistic suicide and anomic suicide (known as altruistic suicide and fatalistic suicide, respectively) are also related to high suicide rates, but were not generally applicable to modern western societies ${ }^{18}$. Divorce has been seen as a behavior which will increase the suicide rate in a society since it both weakens social integration and implies already weakened social regulation, at least in a society where divorce is not yet the norm ${ }^{19}$. The same idea could be applied to unemployment, which implies the loss of social contact and activity, and often leads to the severing of social ties ${ }^{20}$.

The homicide rate in Brazil in 2007 was 26.8 per 100,000 per year, it was considered high compared with the worldwide homicide rate $(8.8)^{6,21}$. In Brazil, homicide rates rose from 27 per 100,000 in 1991 to 32 in 2003, but by 2007 the homicide had declined back to the level seen in $1991^{21}$. Homicide rates in Brazilian states vary broadly, ranging from 11 in Santa Catarina (south) to 51 in Pernambuco (northeast) ${ }^{22}$. The results of ecological studies of homicide rate in Brazil have been consistent with results from other countries, with associations documented between homicide rates and poor socioeconomic conditions ${ }^{21,23,24}$. 
According to Susser and Susser ${ }^{25}$ contextual characteristics are fundamental for understanding the health of persons and groups since measures of individual attributes cannot detect the processes involved in social relationships such as mate selection, social interaction, other behaviors. Although ecological studies do not permit cause-and-effect conclusions (because of their correlational methodology), they can suggest new hypotheses and issues for study ${ }^{26}$. The present article describes for the first time an ecological study of suicide as well as homicide in Brazilian states using an archival data.

\section{Method}

The present study is a cross-sectional ecological study using suicide, homicide and sociodemographic data in the 27 states of Brazil as the unit of analysis. Deaths considered to be suicide were those that used codes corresponding to "intentional self-harm" (X60 to X84). For homicide, the codes used were deaths due to "assault" (X85 to Y09) according to the International Classification of Diseases and Deaths (ICD-10). The mortality database utilized was that of the Ministry of Health Mortality Reporting System ${ }^{27}$. Sociodemographic data were extracted from the National Census (2010) from Instituto Brasileiro de Geografia e Estatística (Brazilian Institute of Geography and Statistics, IBGE) ${ }^{3}$. We chose the year 2010 because it refers to the last national census. Furthermore, there was an improvement in mortality data quality from 2003 onwards ${ }^{9}$. We calculated the ageadjusted rates of suicide and homicide by sex using direct standardization. This approach adjusts crude rates according to the age distribution of one external, arbitrarily-defined population (in this case, Brazilian population was used as a reference, 2010 $)^{3,28}$. The suicide and homicide were defined as dependent variables.

The independent variables used and the corresponding year are listed below:

. Suicide rate (2010)

. Homicide rate (2010)

. \% divorced (2010)

- Gross Domestic Product (GDP) per capita (2008)

. Per capita income (2010)

. \% urban population (2010)

. Population density (2010)

. Birth rate (2009)

. Unemployment rate (2010)
All data investigated are available with freeaccess.

The data were analyzed using SPSS, version 15.0, using correlation techniques, factor analysis, principal component analysis with a varimax rotation and multiple linear regression. Factor analysis and principal components analysis are statistical techniques applied to a single set of variables when the researcher seeks to find out which variables form coherent subsets and are relatively independent of one another. The correlated variables, which are largely independent of other subsets of variables, are combined into factors that form the structures that tend to reflect the underlying processes by the correlations among variables ${ }^{29}$. Variables with a factor load greater than 0.50 were considered to form the factors. Multiple linear regression is used to assess the association between one dependent variable and several independent variables. Multiple linear regression attempts to model the relationship between two or more independent variables $(x)$ and a dependent variable $(y)$ by fitting a linear equation to observed data. Every value of the independent variable is associated with a value of the dependent variable, after controlling for a number of other covariates (e.g., $x_{2}, x_{3}, \ldots x_{n}$ ). The corresponding linear regression model is written as follows:

$$
\begin{array}{ll}
y= & \beta_{0}+\beta_{1} x_{1}+\beta_{2} x_{2} \ldots \beta_{\mathrm{n}} x_{\mathrm{n}} \\
\text { - } & \beta_{0}=\text { the intercept. } \\
\text { - } & \beta_{\mathrm{n}}=\text { regression coefficient }
\end{array}
$$

The regression coefficient (beta) is the estimated increase in the dependent variable $(y)$ per unit increase in the predictor variable $(x)$. This regression coefficient corresponds to the slope of the regression line; it reflects the strength of the association between the variables ${ }^{26}$.

\section{Results}

In the year 2010 , there were 9,423 suicides $(7,352$ men) in Brazil. Suicide rates for the total population, men and women were 5.0, 8.0, and 2.2 per 100,000 inhabitants per year, respectively. The suicide rates of the 27 states ranged from 2.7 in Pará (north) to 9.1 in Rio Grande do Sul (south) (Table 1). In the same year, there were 51,072 homicide victims (46,722 men). Homicide rates for the total population, men and women were 
Table 1. Suicide, homicide, income per capita and unemployment rate among Brazilian states - 2010.

\begin{tabular}{|c|c|c|c|c|c|c|c|c|}
\hline \multirow[b]{2}{*}{ State } & \multicolumn{3}{|c|}{ suicide rates ${ }^{*}$} & \multicolumn{3}{|c|}{ homicide rates $^{*}$} & \multirow{2}{*}{$\begin{array}{l}\text { Income per } \\
\text { capita }^{* *}\end{array}$} & \multirow{2}{*}{$\begin{array}{c}\text { unemployment } \\
\text { rate }(\%)\end{array}$} \\
\hline & men & women & total & men & women & total & & \\
\hline Rondônia & 8.1 & 2.6 & 5.4 & 63.8 & 5.0 & 35.0 & 609.9 & 5.5 \\
\hline Acre & 9.7 & 2.4 & 6.1 & 43.5 & 5.2 & 24.4 & 578.5 & 8.1 \\
\hline Amazonas & 7.8 & 2.0 & 4.9 & 61.1 & 3.8 & 32.4 & 591.1 & 9.8 \\
\hline Roraima & 10.9 & 4.6 & 7.9 & 49.7 & 5.5 & 27.9 & 662.5 & 7.7 \\
\hline Pará & 4.4 & 1.1 & 2.7 & 88.2 & 6.2 & 47.3 & 478.0 & 9.2 \\
\hline Amapá & 8.4 & 1.7 & 5.1 & 73.4 & 6.0 & 39.1 & 660.6 & 11.9 \\
\hline Tocantins & 10.3 & 3.1 & 6.8 & 43.4 & 4.9 & 24.4 & 556.1 & 7.4 \\
\hline Maranhão & 5.8 & 1.2 & 3.5 & 45.6 & 3.7 & 24.3 & 391.9 & 8.7 \\
\hline Piauí & 10.3 & 3.3 & 6.8 & 24.7 & 2.6 & 13.4 & 413.8 & 7.9 \\
\hline Ceará & 9.8 & 2.4 & 6.0 & 62.0 & 4.0 & 32.1 & 435.7 & 7.7 \\
\hline Rio Grande do Norte & 6.9 & 2.2 & 4.5 & 48.1 & 4.4 & 25.7 & 515.0 & 10.0 \\
\hline Paraíba & 7.8 & 1.1 & 4.3 & 74.7 & 6.3 & 39.4 & 450.8 & 8.6 \\
\hline Pernambuco & 5.0 & 1.8 & 3.4 & 77.5 & 5.5 & 40.0 & 491.0 & 11.1 \\
\hline Alagoas & 4.5 & 1.4 & 2.9 & 134.7 & 8.8 & 68.9 & 455.1 & 10.8 \\
\hline Sergipe & 10.1 & 3.1 & 6.5 & 64.8 & 4.1 & 33.3 & 503.2 & 10.3 \\
\hline Bahia & 5.1 & 1.4 & 3.2 & 75.8 & 5.9 & 40.0 & 460.8 & 10.9 \\
\hline Minas Gerais & 8.9 & 2.4 & 5.6 & 33.9 & 4.1 & 18.8 & 623.4 & 6.8 \\
\hline Espírito Santo & 6.9 & 2.2 & 4.5 & 92.7 & 9.7 & 50.5 & 679.1 & 7.3 \\
\hline Rio de Janeiro & 4.4 & 1.8 & 3.0 & 61.8 & 3.9 & 31.8 & 843.8 & 8.5 \\
\hline São Paulo & 7.5 & 1.9 & 4.6 & 24.6 & 3.1 & 13.6 & 857.3 & 7.6 \\
\hline Paraná & 9.1 & 2.2 & 5.6 & 63.1 & 6.3 & 34.2 & 710.4 & 5.0 \\
\hline Santa Catarina & 13.1 & 3.7 & 8.4 & 22.6 & 3.4 & 13.0 & 749.8 & 3.8 \\
\hline Rio Grande do Sul & 15.0 & 3.5 & 9.1 & 36.1 & 4.2 & 19.9 & 723.6 & 4.9 \\
\hline Mato Grosso do Sul & 12.4 & 3.3 & 7.9 & 47.0 & 6.3 & 26.5 & 675.5 & 6.2 \\
\hline Mato Grosso & 8.1 & 3.0 & 5.7 & 56.8 & 5.5 & 31.6 & 672.9 & 6.3 \\
\hline Goiás & 8.3 & 2.3 & 5.3 & 58.6 & 5.8 & 31.9 & 669.4 & 6.3 \\
\hline Distrito Federal & 9.4 & 2.7 & 5.9 & 53.2 & 4.2 & 27.4 & 1391.7 & 8.2 \\
\hline Total & 8.0 & 2.2 & 5.0 & 50.8 & 4.5 & 27.2 & 679.6 & 7.7 \\
\hline
\end{tabular}

${ }^{*}$ age-adjusted rates per 100,000 using the population of Brazil as a reference, 2010. **average monthly income per capita (United States dollar - US\$)

$27.2,50.8$, and 4.5 per 100,000 inhabitants, respectively. The homicide rates of the 27 states ranged from 13.0 in Santa Catarina (south) to 68.9 in Alagoas (northeast).

Suicide and homicide rates were negatively associated over the 27 Brazilian states (Pearson $\mathrm{r}$ $=-0.61$, two-tailed $\mathrm{p}=0.001)$. The negative association was significant for male rates $(r=-0.62, p$ $=0.001)$, but not for female rates $(r=-0.28)$. Unemployment was negatively correlated with suicide and positively with homicide (Table 2).

The principal components analysis identified three components with eigenvalues greater than one. The first factor (accounting for $48.7 \%$ of the variance) had high loadings $(>.50)$ from population density, the divorce rate, urbanization and economic wealth (Table 2). The second factor (accounting for $23.1 \%$ of the variance) had positive loadings from the homicide rate and unem- ployment and a negative loading for the suicide rate. The third factor (accounting for $13.4 \%$ of the variance) had loadings from the birth rate (positively), unemployment rate (positively) and the divorce rate (negatively).

The linear regressions are shown in Table 3. The total suicide rate had three significant coefficients in the multiple regression. The association was negative with the unemployment rate and population density and positive with per capita income. For male suicide rates, result was similar. For female suicide rates, only the unemployment rate was statistically significant.

The total homicide rate (and that for men) had a significant positive association only with the unemployment rate. For women, the homicide rate was positively associated with birth rate and the percentage of divorced persons and negatively associated with the per capita income. 
Table 2. Correlation and factor analysis.

\begin{tabular}{lcccccc}
\hline \multirow{2}{*}{\multicolumn{1}{c}{ Variables }} & \multicolumn{3}{c}{ Component } & & \multicolumn{2}{c}{ Correlations } \\
\cline { 2 - 3 } \cline { 6 - 7 } & $\mathbf{1}$ & $\mathbf{2}$ & $\mathbf{3}$ & & Suicide rate & Homicide rate \\
\hline suicide rate & +0.04 & $-0.92^{\#}$ & +0.01 & & - & - \\
homicide rate & -0.1 & $+0.80^{\#}$ & +0.01 & & $-0.61^{* *}$ & - \\
GDP per capita & $+0.94^{\#}$ & -0.21 & -0.05 & & +0.20 & -0.24 \\
\% urban & $+0.83^{\#}$ & -0.11 & -0.27 & & +0.14 & -0.18 \\
per capita income & $+0.96^{\#}$ & -0.23 & +0.02 & & +0.24 & -0.25 \\
population density & $+0.86^{\#}$ & +0.28 & -0.07 & & -0.21 & +0.01 \\
birth rate & -0.09 & +0.01 & $+0.96^{\#}$ & & -0.01 & +0.13 \\
divorce rate & $+0.69^{\#}$ & -0.27 & $-0.60^{\#}$ & & +0.30 & -0.20 \\
unemployment rate & -0.12 & $+0.74^{\#}$ & $+0.52^{\#}$ & & $-0.63^{* *}$ & $+0.49^{* *}$ \\
\% variance & $48.7 \%$ & $23.1 \%$ & $13.4 \%$ & & & \\
\hline
\end{tabular}

${ }^{\#}$ loading $>0.50$. ${ }^{*}$ two-tailed $\mathrm{p}<0.01$. ${ }^{* *}$ two-tailed $\mathrm{p}<0.001$.

Table 3. Regressions (betas shown).

\begin{tabular}{lcccccccc}
\hline \multirow{2}{*}{\multicolumn{1}{c}{ Variables }} & \multicolumn{3}{c}{ Suicide rate } & & \multicolumn{3}{c}{ Homicide rate } \\
\cline { 2 - 5 } \cline { 6 - 8 } & Total & Male & Female & & Total & Male & Female \\
\hline GDP per capita & -0.75 & -0.66 & -0.91 & & +0.60 & +0.55 & +0.81 \\
\% urban population & -0.14 & -0.07 & -0.42 & & -0.23 & -0.22 & -0.29 \\
Population density & $-0.40^{\#}$ & $-0.39^{\#}$ & -0.29 & & +0.01 & +0.08 & -0.48 \\
Birth rate & +0.04 & -0.03 & +0.11 & & +0.29 & +0.26 & $+0.40^{\#}$ \\
Divorce rate & -0.05 & -0.17 & +0.30 & & $+0.92^{*}$ & +0.86 & $+1.44^{* * \#}$ \\
Unemployment rate & $-0.54^{* \#}$ & $-0.56^{* \#}$ & $-0.36^{\#}$ & & $+0.72^{* \#}$ & $+0.72^{* \#}$ & $+0.73^{*}$ \\
Per capita income & $+1.24^{\#}$ & $+1.17^{\#}$ & +1.37 & & -1.09 & -1.04 & $-1.13^{\#}$ \\
$\mathrm{R}^{2}$ & 0.53 & 0.51 & 0.43 & & 0.37 & 0.39 & 0.35 \\
\hline
\end{tabular}

"two-tailed $<0.10{ }^{* *}$ two-tailed $\mathrm{p}<0.05 .{ }^{*}$ significant in a backward multiple regression.

\section{Discussion}

Suicide and homicide rates were negatively associated in Brazil, both for the overall rates and the male rates. In developing countries, the same pattern has been reported in Trinidad and Tobago $^{30}$, but not in India ${ }^{31}$. In Russia, research has suggested a direct association between suicide and homicide ${ }^{32,33}$. Suicide and homicide rates are not correlated in the United States ${ }^{34}$. Regarding the correlation between suicide and homicide rates across nations worldwide, negative correlations were reported for the countries of the Asia-Pacific region (without India) and the Americas and positive correlations across European countries. Correlations were more pronounced among men, and Bills and $\mathrm{Li}^{35}$ attributed this difference to regional differences in social and cultural variables.
Henry and Short ${ }^{36}$ suggested that, when people have a clear external source to blame for their misery, depression will be less likely and anger more likely. On the other hand, when people have no one to blame but themselves for their misery, depression will be more likely and anger less likely. Based on this, Lester ${ }^{37}$ argued that in regions in which the quality of life is better, suicide rates would be higher, and homicide rates lower since, when the quality of life is better, there are fewer external factors to blame for one's own misery and unhappiness. Lester tested this hypothesis in several regions worldwide, among countries ${ }^{38,39}$, American states ${ }^{37,40}$, American cities ${ }^{41-43}$ and among regions of Great Britain ${ }^{44}$. In a total of eight studies, five confirmed the prediction, two did not ${ }^{41,44}$, and one was inconclusive ${ }^{45}$. In Brazil this prediction has not been tested yet. In the city 
of São Paulo it is known that suicide rates clustered in downtown, in the wealthiest areas ${ }^{46}$, homicide rates clustered mostly in the periphery ${ }^{47}$. Further research is needed to clarify this hypothesis in other regions. However, the present results indicate that regions in Brazil with higher homicide rates have lower suicides. Furthermore, regions in Brazil with high per capita income and lower unemployment rates have higher suicide rates and lower homicide rates. These results suggest that suicide is perhaps more common in regions with a higher quality of life whereas homicide is more common in regions with a lower quality of life.

Being unmarried has been identified as a risk factor for suicide in Western cultures. Higher rates of suicide have been reported among married women in Hong Kong and Pakistan ${ }^{6}$. Individualbased studies in Brazil ${ }^{5,7}$, and an ecological study carried out in the city of Sao Paulo ${ }^{46}$ also identified being unmarried as a risk factor for suicide. However, the present study showed no significant association of this variable with suicide (as measured by the divorce rate among Brazilian states).

Among the states of Brazil, unemployment was negatively correlated with suicide and positively with homicide. In the multiple regression analysis, the overall suicide rate had a significant and positive association with income and a negative association with unemployment and population density. The present results suggest that there is a positive association of suicide rates with socioeconomic characteristics (indexed by income and unemployment). A study focusing on developing countries, using World Health Organization data, revealed a positive association between socioeconomic characteristics (indexed by high education levels, high telephone density, and high cigarette consumption) and suicide ${ }^{16}$. The authors suggested that in developing countries, social deprivation might be more accepted by the population, while in developed countries notions of selfworth and equality are valued. Another explanation, which complements the previous idea, was proposed by Paugam ${ }^{48}$ and Castel ${ }^{49}$ who distinguish between disqualifying and integrated poverty. The latter, which best described Brazil, is observed in societies in which poverty is compensated by solidarity within the family and the neighborhood. On the other hand, disqualifying pover$t y$, which is more common in developed countries, might be related to demotion and loss of social status ${ }^{50}$. Becoming poor in a rich society is, in fact, different than being poor in a poor society.
Lester and Yang ${ }^{19}$, analyzing the theory of Henry and Short ${ }^{36}$, noted that the wealthiest people have more to lose, and so their fall is greater. In Brazil, it is known that the suicide rate is higher in the south ${ }^{7}$. An ecological study also showed that suicide rates were associated with income per capita in Brazil ${ }^{9}$. Studies performed in the capitals of Brazilian states and municipalities that comprise the state of Espírito Santo suggested a possible European influence, since the municipalities with the higher suicide rates were colonized by Europeans, mostly Germans and Italians $^{4,51}$. The WHO's "Self-directed violence" report noted that suicide rates in a given migrant group have been found to be similar to that of the migrant's country-of-birth ${ }^{6}$. Voracek and Loibl $^{52}$ carried out a meta-analysis of 33 studies with data from seven host countries, and found a strong and direct association between immigrant suicide rates and their country-of-birth rates. As the southern region of Brazil is marked by a high rate of European immigration, the cultural aspect cannot be rejected. Further research should examine multiple levels of aggregation to clarify these patterns. It would also be of great interest to study ecological correlations over the different regions within the states and the major cities of Brazil. Are the associations between unemployment rates and suicide and homicide rates documented in the present study over the Brazilian states also found within Brazilian states, and are these associations found for every major city in Brazil or only some?

Unemployment has long been known to be associated with suicidal behavior, using a variety of research designs, including cross-sectional and time series studies and at the individual and aggregate levels ${ }^{53-55}$. A recent systematic review and meta-analysis suggested that long-term unemployment is associated with a greater incidence of suicide ${ }^{56}$. Cross-sectional studies on suicide and unemployment have shown conflicting results. These studies usually test several socioeconomic variables, and sometimes unemployment is one of them. Despite an extensive literature, there have been widely divergent findings regarding the direction of the association between unemployment and suicide rates using aggregate data. This could be related to different definitions of unemployment and levels of aggregation ${ }^{17}$. Lester and Yang ${ }^{19}$ have pointed out, that the association between unemployment and suicide seems to be more reliable at the individual level, as the study of Blakely et al..$^{53}$. An important issue has been raised in some studies concerning the association between 
mental health and unemployment ${ }^{20,54,57}$. Does unemployment worsen the mental health of those who become unemployed or, alternatively, are those with mental health problems more likely to become unemployed? Research has not yet decided between these two possibilities.

Other ecological studies from developing countries showed different results. Although few in number, they have suggested an inverse association between suicide and socioeconomic variables. For example, in Trinidad and Tobago, population density and income were negatively associated with suicide, while East Indian ethnicity and alcohol consumption were positively associated $^{30}$. In India, Pandey ${ }^{31}$ found that the suicide rate was significantly correlated only with high population density. Among the provinces of Ukraine, suicide was strongly associated with indices of social disintegration (indexed by divorce and illegitimacy rates $)^{58}$.

In Taiwan, suicide rates were negatively associated with household income and population density and positively with one-parent households $s^{59}$, while another cross-sectional study carried out in Taiwan showed that low income was the best predictor of suicide rates ${ }^{60}$. In the United States, the pattern of associations differed over time. In 1940, suicide rates were positively associated with income, professionalization and alcohol $^{37}$. In 1980, suicide rates were associated only with population density (negatively) ${ }^{34}$. In 2001 suicide rates were positive correlated with the proportion of men, native American ethnicity and the percentage of uninsured residents; and negative associated with population density, per capita income, psychiatrists per 100,000, physicians per 100,000, mental health aid, and African American ethnicity. After multiple logistic regression, four variables had significant coefficients: male sex, uninsured residents, mental health aid, and psychiatrists per $100,000^{61}$. In Italy, regional suicide rates were positively associated with the employment rate and negatively associated with the economic situation of households ${ }^{62}$. A systematic review of ecological studies in North America, Europe, Australia, and New Zealand, dating from 1897 to 2004, showed that most studies reported a direct association between socioeconomic characteristics (indexed by poverty, unemployment, low educational achievement, and lower occupational social class) and suicide ${ }^{17}$. Moreover, an ecological study that grouped data from the G7 countries reported an association between low income and unemployment with male suicide rates $^{63}$. Other recent ecological studies performed in $\operatorname{Japan}^{64}$, Australia ${ }^{65}$, the west of England ${ }^{66}$, and Finland ${ }^{67,68}$ have also demonstrated a negative association between suicide and socioeconomic characteristics. In developed countries suicide rates have been generally associated with low income, unemployment, educational underachievement, and being single.

Across the states of Brazil, in the linear multiple regressions, the overall homicide rate and that for men had a positive association with unemployment. In Brazil, the homicide rates are higher in young black men and poorly educated people $^{21,24}$. The same pattern has been shown in several Brazilian states ${ }^{69-72}$ and cities $^{73-78}$. For women, our study showed that homicide rates were positively associated with the birth rate and the percentage of divorced persons and negatively associated with per capita income. An ecological study of female homicides in the states of Brazil showed similar pattern. Homicide rates were higher in women aged 20 to 30 years old, with 1 to 3 years of schooling, black and single. In that study, the multiple linear regression indicated that three variables remained significantly associated with female homicide rate: the birth rate, percentage of Evangelicals and the male homicide rate ${ }^{23}$.

Regarding homicide, the results of studies in many nations have produced consistent results. In general, low socioeconomic status (indexed by unemployment, poverty and income inequality) is associated with homicide rates ${ }^{79}$. A study with data from Latin American countries (including Brazil) focused on three levels of variables, from macro-social to micro-social factors, namely: originating (social inequality), promoting (drug markets, impunity, culture of masculinity) and facilitating (alcohol consumption, firearm ownership ${ }^{80}$. Briceno-Leon ${ }^{81}$ investigated two social explanations for homicide, the first attributing its origins to poverty and inequality and the second blaming institutionalization or social norms. His study of homicide trends in Colombia, Venezuela and Brazil in the first decade of the $21^{\text {st }}$ Century, using the technique of trajectory analysis, suggested that social norms were more to blame for the changes than was poverty.

Other studies in developing countries and in developed countries also show interesting findings. In Trinidad and Tobago, the homicide rate was associated with high population density, low marriage rates, African ethnicity and school dropout rates ${ }^{30}$. An ecological study in Russia showed that regions that experienced greater increases in unemployment and that had lower levels of privatization were regions where homicide rates in- 
creased the most ${ }^{82}$. Another study of Russian regions showed that poverty was positively and significantly associated with homicide rates ${ }^{83}$. However, in India, the homicide rates were not associated with any of the social variables ${ }^{31}$. Among the states of the United States (USA), homicide rates were negatively associated with median income ${ }^{84}$. Other studies have shown that homicide rates were associated with income inequality ${ }^{85,86}$ and a high level of urbanization ${ }^{85}$. A cross-national study of 33 countries indicated that income inequality was associated with homicide, partially mediated by an indicator of social capital ${ }^{87}$. Another study of 16 countries (United States and 15 nations from the European Union) found that the infant mortality and the relative poverty were significantly associated with homicide rates ${ }^{88}$.

The present study has some limitations. The first is inherent in the ecological study design. The association observed between variables at the group level does not necessarily represent the association that exists at the individual level. This bias is known as ecological fallacy. Another limitation is related to data collection resulting from possible misclassifications of suicides. Different procedures, as well as cultural and social practices and values probably have an impact on death records and can lead to a misclassification of suicides $^{6,11}$. According to Bertolote et al. ${ }^{89}$, about $20 \%$ of deaths due to external causes in Brazil are recorded only as to mechanism, not intent (e.g., falls and drowning 10.9\%; undetermined intention $8.7 \%$ ), making it impossible to ascertain how many of them are accidents or suicides. However, this type of bias is inevitable in ecological studies of suicidology, and regional differences in classification may not be as large as difference between nations. Additionally, a study carried out in Brazil demonstrated a temporal trend of improvement in the quality of violence-related mortality data in the past two decades ${ }^{90}$.

The present study presented a classical ecological study of suicide and homicide across the Brazilian states. The results provide evidence suggesting that suicide and homicide are negatively correlated in Brazil and that unemployment may be an important determinant for suicide and homicide rates. Suicide rates showed a pattern suggesting that, in Brazil, suicide is related to high socioeconomic status. Homicide rates in Brazil seemed to follow the pattern found in other countries, in other words, associated with lower low socioeconomic status. Further researches are needed to elucidate these patterns.

\section{Collaborations}

DH Bando undertook data extraction and D Lester worked in the analysis. DH Bando wrote the first draft. D Lester formulated research questions and contributed to writing the drafts. All the authors contributed to the preparation of the final manuscript and approved the submission. 


\section{References}

1. Lester D. Patterns of Suicide and Homicide in America. New York: Nova Science Pub Incorporated; 1994

2. Paim J, Travassos C, Almeida C, Bahia L, Macinko J. The Brazilian health system: history, advances, and challenges. Lancet 2011; 377(9779):1778-1797.

3. Instituto Brasileiro de Geografia e Estatística (IBGE). Censo nacional de 2010. [Internet]. [cited 2014 Jan 2]. Available from: http://censo2010.ibge.gov.br/ apps/atlas/

4. Souza ER, Minayo MC, Malaquias JV. Suicide among young people in selected Brazilian State capitals. Cad Saude Publica 2002; 18(3):673-683.

5. Bando DH, Brunoni A, Fernandes T, Bensenor IM, Lotufo PA. Suicide rates and trends in São Paulo, Brazil according to gender, age and demographic aspects: A Joinpoint Regression Analysis. Rev Bras Psiquiatr 2012; 34(3):286-293.

6. World report on violence and health. Chapter 7 . Self-directed violence. 2002. [Internet]. p. 185-212. [cited 2011 Feb 3]. Available from: http://www. who.int/ violence_injury_prevention/violence/global_ campaign/en/chap7.pdf

7. Lovisi GM, Santos SA, Legay L, Abelha L, Valencia E. Epidemiological analysis of suicide in Brazil from 1980 to 2006. Rev Bras Psiquiatr 2009; 31(Supl. 2):S8694.

8. Gawryszewski VP, Sanhueza A, Martinez-Piedra R, Escamilla JA, Souza MFM. Homicídios na região das Américas: magnitude, distribuição e tendências, 1999-2009. Cien Saude Colet 2012; 17(12):31713182 .

9. Bando DH, Brunoni AR, Bensenor IM, Lotufo PA. Suicide rates and income in Sao Paulo and Brazil: a temporal and spatial epidemiologic analysis from 1996 to 2008. BMC Psychiatry 2012; 12:127.

10. Brzozowski FS, Soares GB, Benedet J, Boing AF, Peres MA. Suicide time trends in Brazil from 1980 to 2005. Cad Saude Publica 2010; 26(7):1293-1302.

11. Hawton K, van Heeringen K. Suicide. Lancet 2009; 373(9672):1372-1381

12. Durkheim É. Suicide: a study in sociology. New York: Simon \& Schuster; 1951.

13. Lester D. Suicide from a sociological perspective. Springfield: Charles C Thomas; 1989.

14. Stack S. Suicide: a 15-year review of the sociological literature. Part II: modernization and social integration perspectives. Suicide Life Threat Behav 2000; 30(2):163-176.

15. Stack S. Suicide: a 15-year review of the sociological literature. Part I: cultural and economic factors. Suicide Life Threat Behav 2000; 30(2):145-162.

16. Vijayakumar L, Nagaraj K, Pirkis J, Whiteford H. Suicide in developing countries (1): frequency, distribution, and association with socioeconomic in dicators. Crisis 2005; 26(3):104-111.

17. Rehkopf DH, Buka SL. The association between suicide and the socio-economic characteristics of geographical areas: a systematic review. Psychol Med 2006; 36(2):145-157.

18. Iga M. The Thorn in the Chrysanthemum: Suicide and Economic Success in Modern Japan. Berkeley and Los Angeles: University of California Press; 1986.
19. Lester D, Yang B. The Economy and Suicide: Economic Perspectives on Suicide. New York: Nova Science Publishers; 1997.

20. Preti A. Unemployment and suicide. J Epidemiol Community Health 2003; 57(8):557-578.

21. Reichenheim ME, de Souza ER, Moraes CL, de Mello Jorge MH, da Silva CM, de Souza Minayo MC. Violence and injuries in Brazil: the effect, progress made, and challenges ahead. Lancet 2011; 377(9781):1962-1975.

22. Nadanovsky P, Celeste RK, Wilson M, Daly M. Homicide and impunity: an ecological analysis at state level in Brazil. Rev Saude Publica 2009; 43(5):733-742.

23. Meneghel SN, Hirakata VN. Femicides: female homicide in Brazil. Rev Saude Publica 2011; 45(3):564574 .

24. Soares Filho AM. Homicide victimization according to racial characteristics in Brazil. Rev Saude Publica 2011; 45(4):745-455.

25. Susser M, Susser E. Choosing a future for epidemiology: I. Eras and paradigms. Am J Public Health 1996; 86(5):668-673.

26. Szklo M, Nieto FJ. Epidemiology: beyond the basics. Sudbury: Jones and Bartlett Publishers; 2007.

27. Brasil. Ministério da Saúde (MS). Departamento de Informática do Sistema Único de Saúde (Datasus). 2012. [cited 2011 Feb 3]. Available from: http:// www2.datasus.gov.br/DATASUS/index.php

28. Ahmad OB, Boschi-Pinto C, Lopez A, Murray C, Lozano R, Inoue M. A new WHO standard population. Age standardization of rates: a new WHO standard. Geneva: World Health Organization; 2001. GPE Discussion Paper Series.

29. Sato RC, Zouain DM. Factor analysis for the adoption of nuclear technology in diagnosis and treatment of chronic diseases. Einstein (Sao Paulo) 2012; 10(1):62-26.

30. Hutchinson G. Variation of homicidal and suicidal behaviour within Trinidad and Tobago and the associated ecological risk factors. West Indian Med J 2005; 54(5):319-324.

31. Pandey R. Suicide and social structure in India. Social Defence 1986; 21(83):5-29.

32. Pridemore WA. Demographic, Temporal, and Spatial Patterns of Homicide Rates in Russia. European Sociological Review 2003; 19:41-59.

33. Pridemore WA, Spivak AL. Patterns of Suicide Mortality in Russia. Suicide and Life-Threatening Behavior 2003; 33(2):132-150.

34. Lester D, Agarwal K, Natarajan M. Suicide in India. Archives of Suicide Research 1999; 5(2):91-96.

35. Bills CB, Li G. Correlating homicide and suicide. Int J Epidemiol 2005; 34(4):837-845.

36. Henry AF, Short JF. Suicide and homicide: some economic, sociological, and psychological aspects of aggression. New York: Free Press; 1954.

37. Lester D. Suicide, homicide, and the quality of life: an archival study. Suicide Life Threat Behav 1986; 16(3):389-392.

38. Lester D. The association between the quality of life and suicide and homicide rates. J Soc Psychol 1984; 124:247-248. 
39. Lester D. Suicide, homicide and the quality of life in various countries. Acta Psychiatr Scand 1990; 81(4):332-334.

40. Lester D. The quality of life and suicide. The Journal of Social Psychology 1985; 125(2):279-280.

41. Lester D. The quality of life in modern America and suicide and homicide rates. J Soc Psychol 1985; 125(6):779-780.

42. Lester D. The quality of life and suicide rates in American cities in 1930. Psychol Rep 1989; 65(3 Pt 2):1358.

43. Lester D. The quality of life in urban areas and suicide. Percept Mot Skills 1993; 77(2):482.

44. Lester D. The quality of life and suicide in Great Britain. Percept Mot Skills 1996; 82(3):1386.

45. Lester D. Murders and suicide: Are they polar opposites. Behavioral Sciences \& the Law 1987; 5(1):4960.

46. Bando DH, Moreira RS, Pereira JC, Barrozo LV Spatial clusters of suicide in the municipality of Sao Paulo 1996 - 2005: an ecological study. BMC Psychiatry 2012; 12:124.

47. Ceccato V. Homicide in São Paulo, Brazil: assessing spatial-temporal and weather variations. Journal of Environmental Psychology 2005; 25(3):307-321.

48. Paugam S. Desqualificação social - ensaio sobre a nova pobreza. São Paulo: Educ \& Cortez; 2003.

49. Castel R. Metamorfoses da questão social. Rio de Janeiro: Vozes; 1998.

50. Baudelot C, Establet R. Suicide: The hidden side of mordernity. Cambridge: Polity Press; 2008.

51. Macente LB, Zandonade E. Spatial distribution of suicide incidence rates in municipalities in the state of Espírito Santo (Brazil), 2003-2007: spatial analysis to identify risk areas. Rev Bras Psiquiatr 2012; 34(3):261-269.

52. Voracek M, Loibl LM. Consistency of immigrant and country-of-birth suicide rates: a meta-analysis. Acta Psychiatr Scand 2008; 118(4):259-271.

53. Blakely TA, Collings SC, Atkinson J. Unemployment and suicide. Evidence for a causal association? J Epidemiol Community Health 2003; 57(4):594600.

54. Lester D, Yang B. Unemployment and suicidal behaviour. J Epidemiol Community Health 2003. 57(8):558-559.

55. Platt $S$. Unemployment and suicidal behaviour: a review of the literature. Soc Sci Med 1984; 19(2):93115.

56. Milner A, Page A, Lamontagne AD. Long-term unemployment and suicide: a systematic review and meta-analysis. PloS one 2013; 8(1):e51333.

57. Kposowa AJ. Research on unemployment and suicide. J Epidemiol Community Health 2003; 57(8):559560.

58. Kondrichin SV, Lester D. Suicide in the Ukraine. Crisis 2002; 23(1):32-33.

59. Chang SS, Sterne JA, Wheeler BW, Lu TH, Lin JJ, Gunnell D. Geography of suicide in Taiwan: spatial patterning and socioeconomic correlates. Health Place 2011; 17(2):641-650.

60. Chuang HL, Huang WC. A reexamination of "sociological and economic theories of suicide: a comparison of the U.S.A. and Taiwan". Soc Sci Med 1996; 43(3):421-423.
61. Tondo L, Albert MJ, Baldessarini RJ. Suicide rates in relation to health care access in the United States: an ecological study. J Clin Psychiatry 2006; 67(4):517523.

62. Pompili M, Innamorati M, Vichi M, Masocco M, Vanacore N, Lester D, Serafini G, Tatarelli R, De Leo D, Girardi P. Inequalities and impact of socioeconomic-cultural factors in suicide rates across Italy. Crisis 2011; 32(4):178-185

63. Ying YH, Chang K. A study of suicide and socioeconomic factors. Suicide Life Threat Behav 2009; 39(2):214-226.

64. Fukuda Y, Nakamura K, Takano T. Cause-specific mortality differences across socioeconomic position of municipalities in Japan, 1973-1977 and 19931998: increased importance of injury and suicide in inequality for ages under 75. Int J Epidemiol 2005; 34(1):100-109.

65. Taylor R, Page A, Morrell S, Harrison J, Carter G. Mental health and socio-economic variations in Australian suicide. Soc Sci Med 2005; 61(7):15511559.

66. Rezaeian M, Dunn G, St Leger S, Appleby L. Ecological association between suicide rates and indices of deprivation in the north west region of England: the importance of the size of the administrative unit. J Epidemiol Community Health 2006; 60(11):956-961.

67. Maki N, Martikainen P. The role of socioeconomic indicators on non-alcohol and alcohol-associated suicide mortality among women in Finland. A register-based follow-up study of 12 million personyears. Soc Sci Med 2009; 68(12):2161-2169.

68. Maki NE, Martikainen PT. Socioeconomic differences in suicide mortality by sex in Finland in 19712000: a register-based study of trends, levels, and life expectancy differences. Scand J Public Health 2007; 35(4):387-395.

69. Batista LE, Escuder MM, Pereira JC. The color of death: causes of death according to race in the State of Sao Paulo, 1999 to 2001. Rev Saude Publica 2004; 38(5):630-636

70. Kilsztain S, do Carmo MS, Sugahara GT, Lopes Ede S. Victims of color: homicides in Greater Metropolitan Sao Paulo, Brazil, 2000. Cad Saude Publica 2005; 21(5):1408-1415.

71. Hennington ÉA, Meneghel SN, Barros FdS, Silva LB, Grano MS, Siqueira TP, Stefenon C. Mortalidade por homicídios em Município da Região Sul do Brasil, 1996 a 2005. Revista Brasileira de Epidemiologia 2008; 11(3):431-441.

72. Lima ML, Ximenes RAA, Souza ER, Luna CF, Albuquerque MFPM. Spatial analysis of socioeconomic determinants of homicide in Brazil. Rev Saude Publica 2005; 39(2):176-182.

73. Macedo AC, Paim JS, Silva LM, Costa Md Mda C. Violence and social inequalities: mortality rates due to homicides and life conditions in Salvador, Brazil. Rev Saude Publica 2001; 35(6):515-522.

74. Gawryszewski VP, Costa LS. Social inequality and homicide rates in Sao Paulo City, Brazil. Rev Saude Publica 2005; 39(2):191-197.

75. Santos SM, Barcellos C, Carvalho MS, Flores R. Spatial clusters detection of violent deaths in Porto Alegre, Rio Grande do Sul, Brazil, 1996. Cad Saude Publica 2001; 17(5):1141-1151. 
76. Bastos MJRP, Pereira JA, Smarzaro DC, Costa EF, Bossanel RC, Oliosa DM, Pereira JG, Feitosa HN, Costa MF, Oliveira FJ, Fávero JL, Maciel EL. Ecological analysis of accidents and lethal violence in Vitoria, Southeastern Brazil. Rev Saude Publica 2009; 43(1):123-132.

77. Minamisava R, Nouer SS, Neto OL, Melo LK, Andrade AL. Spatial clusters of violent deaths in a newly urbanized region of Brazil: highlighting the social disparities. Int J Health Geogr 2009; 8:66.

78. Ruotti C, Freitas TV, Almeida JF, Peres MF. Gross violation of human rights and inequality in city of Sao Paulo, Southeastern Brazil. Rev Saude Publica 2009; 43(3):533-540.

79. Hsieh CC, Pugh MD. Poverty, Income Inequality, and Violent Crime: A Meta-Analysis of Recent Aggregate Data Studies. Criminal Justice Review 1993 18(2):182-202.

80. Briceno-Leon R, Villaveces A, Concha-Eastman A. Understanding the uneven distribution of the incidence of homicide in Latin America. Int J Epidemiol 2008; 37(4):751-757.

81. Briceno-Leon R. Understanding homicides in Latin America: poverty or institutionalization? Cien Saude Colet 2012; 17(12):3159-3170.

82. Pridemore WA, Kim SW. Socioeconomic Change and Homicide in a Transitional Society. Sociol $Q$ 2007; 48(2):229-251.

83. Kim SW, Pridemore WA. Poverty, Socioeconomic Change, Institutional Anomie, and Homicide. Soc Sci Q 2005; 86(S1):1377-1398.

84. Kaplan GA, Pamuk ER, Lynch JW, Cohen RD, Balfour JL. Inequality in income and mortality in the United States: analysis of mortality and potential pathways. BMJ 1996; 312(7037):999-1003.

85. Cubbin C, Pickle LW, Fingerhut L. Social context and geographic patterns of homicide among US black and white males. Am J Public Health 2000; 90(4):579-587.

86. Kennedy BP, Kawachi I, Prothrow-Stith D. Income distribution and mortality: cross sectional ecological study of the Robin Hood index in the United States. BMJ 1996; 312(7037):1004-1007.

87. Elgar FJ, Aitken N. Income inequality, trust and homicide in 33 countries. Eur J Public Health 2011; 21(2):241-246

88. Messner SF, Raffalovich LE, Sutton GM. Poverty, Infant Mortality, and Homicide Rates in CrossNational Perpsective: Assessments of Criterion and Construct Validity. Criminology 2010; 48(2):509-537.

89. Bertolote JM, Botega $\mathrm{N}$, de Leo D. Inequities in suicide prevention in Brazil. Lancet 2011; 378(9797): 1137.

90. Alazraqui M, Spinelli H, Zunino MG, Souza ERd. Calidad de los sistemas de información de mortalidad por violencias en Argentina y Brasil - 19902010. Cien Saude Colet 2012; 17(12):3279-3288.

Artigo apresentado em 16/03/2013

Aprovado em 27/07/2013

Versão final apresentada em 14/08/2013 
